\title{
Pattern of Labor Mobility Study Case: Fourteen Metropolitan Areas in Indonesia
}

\author{
Hazmi Achmad Gaffar ${ }^{1}$, I.G.A.A Karishma Maharani Raijaya ${ }^{2}$ Chotib $^{3}$ \\ \{hazmi.gaffar@gmail.com ${ }^{1}$, maharanirisma01@gmail.com², chotib.m@ui.ac.id ${ }^{3\}}$ \\ ${ }^{1}$ Faculty of Economics and Business, Universitas Indonesia, ${ }^{2}$ Master in Economics of \\ Population and Labor Economics (MEKK), Universitas Indonesia, ${ }^{3} \mathrm{Head}$ of Urban \\ Studies Program School of Strategic and Global Studies (SKSG) Universitas Indonesia
}

\begin{abstract}
Mobility is part of Economic and Labor Activities, and it would happen naturally. Skeldon, in his theory, said that labor mobility has a variation of the pattern depends on the socio-economics of the society. This article will examine the impact of demographic characteristics and location of housing at fourteen metropolitan areas in Indonesia. With the multinomial logit regression method, the writer found that in general, the examined factors have a similar impact upon mobility pattern at every metropolitan area in Indonesia, although in some cases, there were differences in correlation results between a specific variable against mobility pattern.
\end{abstract}

Keywords: Demographic Characteristic, Mobility, Metropolitan Area, Labor.

\section{Introduction}

According to urban economists. an urban area is a geographical area that contains large numbers of people in a relatively small area. In other words, metropolitan areas have a high population density compared to densities in the surrounding regions (O'Sullivan, 2012). Based on these definitions, a city can describe the many different types of economic activity that occur in a relatively small place. Because of the limited land to produce agricultural goods, residents in the city must create other assets so that they can exchange them for food products. Finally, there are new types of work and new job opportunities.

In line with the Ravenstein's theory (1885) that there are four factors influence a person to carry out migration, namely: pull factor and push element, the existing barrier factors as well as internal factors. Diversification of the type of work that occurs in the city will be one of the pull factors for rural communities to carry out urbanization. Villagers consider work in the city to be more profitable, and less capital need compared to production in agriculture in rural area and choose to work in the city. That thing will make a shift in the population from villages to cities.

When a city continues to grow, the demand for land to open new jobs will increase following the significant employment from its population. This increase will have an impact on the decreasing supply for housing because urban land is used for economic activities. Limited housing supply will certainly limit population growth so that in the end, the city may be short of workers. Because of this problem, the Metropolitan area emerged and integrated with the surrounding area. With the integration of this metropolitan area, the central city land can be focused on economic activities while the residential area would be placed in the suburbs or even the outside the administrative area of the city.

The changes in spatial shape of the city certainly will change the pattern of the mobility of the people. With the emergence of the metropolitan area, it means that there will be many workers from outside the central city who come and become commuter or circular residents. 
Let's take Jabodetabek as example, according to the Survey Komuter Jabodetabek 2014, and there were 13 percent of the population commuting with 74 percent of the commuter population aged 15-44 years old and the number of men compared to women reached 2: 1

Table 1. Jabodetabek Commuter Flow Between Regencies / Cities 2014 (Partly)

\begin{tabular}{|c|c|c|c|c|c|c|c|c|}
\hline \multirow[b]{2}{*}{ Destination } & \multirow[b]{2}{*}{$\begin{array}{c}\text { South } \\
\text { Jakarta }\end{array}$} & \multirow[b]{2}{*}{$\begin{array}{c}\text { East } \\
\text { Jakarta }\end{array}$} & \multicolumn{4}{|c|}{ Commuter Destination } & \multirow[b]{2}{*}{$\begin{array}{c}\text { Tangerang } \\
\text { Cities }\end{array}$} & \multirow[b]{2}{*}{ Total } \\
\hline & & & $\begin{array}{l}\text { Center } \\
\text { Jakarta }\end{array}$ & $\begin{array}{c}\text { West } \\
\text { Jakarta }\end{array}$ & $\begin{array}{l}\text { Bogor } \\
\text { Cities }\end{array}$ & $\begin{array}{l}\text { Bekasi } \\
\text { Cities }\end{array}$ & & \\
\hline $\begin{array}{l}\text { Bogor } \\
\text { Cities }\end{array}$ & 7.034 & 5.937 & 8.370 & 5.345 & - & - & 354 & 72.102 \\
\hline $\begin{array}{l}\text { Bogor } \\
\text { Regencies }\end{array}$ & 44.665 & 20.457 & 48.158 & 17.414 & 168.899 & 16.633 & 5.194 & 427.908 \\
\hline $\begin{array}{l}\text { Bekasi } \\
\text { Cities }\end{array}$ & 71.463 & 154.175 & 73.924 & 23.368 & 549 & - & 3.378 & 460.069 \\
\hline $\begin{array}{l}\text { Bekasi } \\
\text { Regencies }\end{array}$ & 3.359 & 63.126 & 20.431 & 7.869 & 335 & 71.087 & 373 & 224.101 \\
\hline $\begin{array}{l}\text { Tangerang } \\
\text { Cities }\end{array}$ & 55.556 & 3.724 & 34.446 & 89.864 & 396 & 554 & - & 283.779 \\
\hline $\begin{array}{l}\text { Tangerang } \\
\text { Regencies }\end{array}$ & 7.764 & 2.505 & 11.990 & 25.717 & - & - & 106.224 & 182.455 \\
\hline $\begin{array}{l}\text { Bogor } \\
\text { Cities }\end{array}$ & $9,8 \%$ & $8,2 \%$ & $11,6 \%$ & $7,4 \%$ & - & - & $0,5 \%$ & $100,0 \%$ \\
\hline $\begin{array}{l}\text { Bogor } \\
\text { Regencies }\end{array}$ & $10,4 \%$ & $4,8 \%$ & $11,3 \%$ & $4,1 \%$ & $39,5 \%$ & $3,9 \%$ & $1,2 \%$ & $100,0 \%$ \\
\hline $\begin{array}{l}\text { Bekasi } \\
\text { Cities }\end{array}$ & $15,5 \%$ & $33,5 \%$ & $16,1 \%$ & $5,1 \%$ & $0,1 \%$ & - & $0,7 \%$ & $100,0 \%$ \\
\hline $\begin{array}{l}\text { Bekasi } \\
\text { Regencies }\end{array}$ & $1,5 \%$ & $28,2 \%$ & $9,1 \%$ & $3,5 \%$ & $0,1 \%$ & $31,7 \%$ & $0,2 \%$ & $100,0 \%$ \\
\hline $\begin{array}{l}\text { Tangerang } \\
\text { Cities }\end{array}$ & $19,6 \%$ & $1,3 \%$ & $12,1 \%$ & $31,7 \%$ & $0,1 \%$ & $0,2 \%$ & - & $100,0 \%$ \\
\hline $\begin{array}{l}\text { Tangerang } \\
\text { Regencies }\end{array}$ & $4,3 \%$ & $1,4 \%$ & $6,6 \%$ & $14,1 \%$ & - & - & $58,2 \%$ & $100,0 \%$ \\
\hline
\end{tabular}

Source: Survei Komuter Jabodetabek 2014.

Table 1. shows the non-permanent mobility patterns in Jabodetabek. Workers who live in district areas will tend to go to the nearest city, and then choose to go to the central city. While city workers will reduce to go to the central cities. In the case of Jabodetabek, the destination of commuter workers is the administrative city closest to where they live. The number of 
commuters from Bekasi, who went to East Jakarta proved the tendency of workers to go to the nearest administrative city and the number reached 150 thousand people.

Like the example above, in other metropolitan areas, it will undoubtedly have a unique pattern in the mobility of its workers, or maybe for Jabodetabek, the year change can also change the mobility patterns that occur. Therefore, this study will try to analyze and estimate the effect of demographic characteristics and the choice of residence location of workers in the metropolitan area on their decision to engage in non-permanent mobility.

\section{Literature Review}

\subsection{Metropolitan Area Creation}

Based on the Undang-Undang Republik Indonesia num.26, 2007, metropolitan area is a core urban area and there are surrounding urban areas that have functional interconnections connected to an integrated regional infrastructure network system with a population of at least 1,000,000 (one million) people (Indonesia, 2007).

The Metropolitan Area is an area that consists of a densely populated urban core and a less crowded surrounding area, sharing industry, sharing infrastructure, and sharing housing. The metropolitan area combines urban agglomeration (adjacent areas and built-up areas) with zones that do not have to be downtown but are tightly bound to the central city through work or other economic activities (Squires, 2002). These small zones are sometimes known as commuter belts, and they can extend beyond the urban zone to reach other regional political areas. So it is not uncommon for metropolitan areas to eventually merge several cities that have decentralized their respective governments.

According to the 2015-2019 National Development Planning Board RPJMN, there are 10 regions that have become metropolitan areas in Indonesia, In this study there are also four additional areas which, according to the author, have been declared by the regional government or have been planned to become a metropolitan area in the next few years. These areas include:

1. Mebidangro which provides for Medan City, Binjai City, Deli Serdang Regency, Karo Regency

2. Palapa which provides for Padang City, Padang City, Padang Pariaman Regency (Pariaman Today)

3. Patungraya Agung which provides for Palembang City, Banyuasin Regency, Ogan Ilir Regency, Ogan Komering Ilir Regency

4. Jabodetabek which covers West Jakarta City, Central Jakarta City, South Jakarta City, East Jakarta City, North Jakarta City, Kepulauan Seribu Regency, Bogor Regency, Bogor City, Depok City, Tangerang Regency, Tangerang City, South Tangerang City, Bekasi City, Bekasi Regency

5. Bandung Raya which provides for the City of Bandung, Bandung Regency, West Bandung Regency, Cimahi City

6. Kedungsepur which provides for Semarang City, Kendal Regency, Salatiga City, Semarang Regency, Demak Regency, Grobogan Regency

7. Kartamantul which covers Yogyakarta City, Sleman Regency, Bantul Regency (Utama, 2016)

8. Solo Raya which includes Surakarta City, Boyolali Regency, Sukoharjo Regency, Karanganyar Regency, Wonogiri Regency, Sragen Regency, Klaten Regency (Solo Baru)

9. Gerbangkertosusila which covers Surabaya City, Sidoarjo Regency, Gresik Regency, Mojokerto Regency, Lamongan Regency, Bangkalan Regency, Mojokerto City 
10. Sarbagita which includes Denpasar City, Badung Regency, Gianyar Regency, Tabanan Regency

11. Mataram Raya which covers the city of Mataram, West Lombok Regency, East Lombok Regency, Central Lombok Regency, North Lombok Regency (Ciptakarya, 2018)

12. Banjar Bakula which provides for Banjarmasin City, Banjarbaru City, Banjar Regency, Barito Kuala Regency, Tanah Laut Regency

13. Mamminasata which provides for Makassar City, Maros Regency, Gowa Regency, Takalor Regency

14. Binondo which provides for Manado City, Bitung City, Minahasa Regency

\subsection{Migration Theory and Non-Permanent Mobility Theories}

According to Zelinsky (1971) in the theory of Migration Transition Model, claiming that the pattern of mobility in a country depends on how developed the community or type of people in the country. To connect between mobility patterns and society, Zelinsky uses the migration stages in the Demographic Transition Model (DTM). According to him, there are five stages in the development of society: (1) Pre-modern Traditional Societies, (2) Early Transition Society, (3) Final Transition Society, (4) Advanced Society, and (5) A Very Advanced Future Society.

Based on Zelinsky's theory, Skeldon (1990) tried to perfect the Migration Transition theory by analyzing migration patterns in developing countries. Skeldon developed the Zelinsky transition stage into seven transition stages: 1) pre-transition society, 2) early transition society, 3) intermediate transition society, 4) late transition society, 5) early advanced society, 6) advanced advanced society, and 7) super developed society.

\subsection{Non-Permanent Mobility}

In looking at determinants of non-permanent mobility patterns, Thompson (1956) tried to examine the habit of commuting in workers in manufacturing. Some of the conclusions he got were first in rural areas, especially if the city is a dining area with high unemployment, and low agricultural income will have a long commuter distance. Both stretches of toll road drive commuting distances increase. The three large factory areas in the village will have more influence on long-distance commuter patterns than if in the city. The four hourly-paid workers will have more commuting distances than white-collar workers or supervisors. The five men have longer commuting time and workers who are married tend to commute further. Middleaged workers dominate the six groups of long-distance commuter workers compared to young and old workers.

Punpuing (1992) argues that commuting has a role in the adjustment process between residence and workplace. In his research, he tried to look at the effects of demography, socioeconomics, and social environment on two selection processes: stage 1 - work at home or office, stage 2 - choice of distance and commuter time in the city of Bangkok. In his research results stated that age, sex, occupation, and duration of stay currently have a relationship with the location of the workplace. Punpuing also added that the pattern of commuting is more determined by socioeconomic factors than other factors. The high cost of living in Bangkok forces workers to focus more on income maximization compared to family affairs or the social environment.

Many factors that can influence someone to do social mobility, Preston, McLafferty, and Hamilton (1993) try to see the effect of family status on the mobility patterns of women of various races in the city of New York. In that study, they concluded that women with higher 
family responsibilities would have shorter commuter times. According to their hypothesis that unmarried women have a longer commuter time than married women, although the average of both of them is still below the average of overall workers. However, family influence does not affect the case of racial minority women in New York such as black women or Hispanic women. The presence of children, children's age, and marital status has only a small effect on the average commute time. Further research, found that marital status had a lower impact than run on the pattern of female commuting in New York.

Based on the findings made by Djist \& Schwanen (2001) regarding the relationship between commuter time and duration of work with the Netherlands as a scope of research. Using the concept of the travel time ratio in this study, they found that in the Netherlands, the average person would use about $10.5 \%$ or 28 minutes of their time if they had eight hours of work a day. They added that these results still vary in different socio-demographics.

Like Preston and friends, Lee and McDonald (2002), in their study of the determinants of the distance and time of commuting in the Seoul area, Korea tried to look at relationships with married people. In their research, they found that married women have faster commuting times than other workers (married/unmarried men and unmarried women), and the difference in commuter time between men and women will increase as the level of education decreases. Even though it is faster, it turns out the commuter time of married women is only 9-10 minutes faster than married men, not too much time difference. They added that significantly the traveling pattern of married women was influenced by the presence of children and the number of their children. Then if there are parents or in-laws of a female worker, this can substantially increase her commuter time. In this Lee and McDonald research, they concluded that when a worker, the woman who will have a higher influence on the pattern of mobility.

In the Kawase research results (2004) regarding differences in commuter patterns between men and women in the Tokyo metropolitan area conclude two things, namely: 1) there are differences in outcomes between generations where male workers tend to have a longer commuter time compared to women. Whereas in the case of boys and girls, the results obtained are just the opposite, the commuting time of girls tends to be longer than boys. Kawase believes this can happen because of a Japanese tradition where parents will forbid their daughters from living alone, so girls are forced to do long-distance commuting. Finally, for married women, they tend to quit their jobs and choose to become a housewife due to restrictions on managing the home and looking after children.

Based on Trendle and Siu's (2005) research, they tried to examine the pattern of commuting in the city of Sunhine Coast at different levels of education. In his study, higher education relatively has a longer commuting time. They indicate that people with higher education will be increasingly insensitive to the conditions between origin and destination; the main thing that workers pay attention to is higher incomes.

Axisa et al. (2012) tried to see the relationship between migration, location of residence, and commuting distance with commuting patterns in the Toronto area. In this research, they found that workers who are migrant workers will have a longer commuter time than residents who have lived for a long time. The more extended the person's stay is, the shorter the commuting distance will be. 


\section{Methodology}

Source and Structure of Data

In conducting this research, the analysis will use secondary data sourced from the results of the 2018 semester II National Labor Force Survey (Sakernas) conducted by the Indonesian Central Statistics Agency (BPS). Sakernas is a survey conducted by BPS to collect employment data in Indonesia continuousl. Since 2005 until now, Sakernas has been conducted every semester in February and August. Since 2008, information collected by Sakernas has been broken down to the district/city level with additional information.

\subsection{Model}

The analytical method in this study are:

1. Descriptive analysis to provide a general description of the interrelationships between the variables used in this study

2. Inferential analysis with a regression model to estimate the effect of the independent variables used on the related variables.

In descriptive analysis, tabulation will show the mobility pattern variables and some of the variables studied. This tabulation will describe the distribution of existing mobility patterns based on independent variables in each Metropolitan area. Then after the tabe of variables is made, an analysis will be carried out by looking at similarities in trends occurring on the results of the table of dependent and independent variables between Metropolitan areas.

In inferential analysis, the regression estimation model used is the Multinomial Logistic Regression analysis model. According to Bruin (2006), multinomial logistic regression is used to model the categorized outcome variables, where the probability of the results contained in the model is a linear combination of the predictor variables. This method is used because: First, the mobility pattern variable cannot be expressed in numerical or categorical form. The appropriate regression method is the logit or probit method, but because the respondent's distribution is not a normal distribution, it uses logit. Second, among several types of logit models, multinomial logits are chosen because each category does not have different levels.

Based on the Susiyanto, Multinomial Logistic model (2018), the models in this study are:

$$
\begin{aligned}
& \ln \left(\frac{P_{1}}{P_{0}}\right)=\beta_{0}+\beta_{1} \text { DISTANCE }+\beta_{2} \text { CLASSIFICATION }+\beta_{3} \text { GENDER }+\beta_{4} \mathrm{AGE}+\beta_{5} \text { EDUCATION } \\
& +\beta_{6} \text { STATUS }+\beta_{7} A V G_{-} W O R K+\beta_{8} W O R K_{-} C L A S S+\varepsilon_{9} \\
& \ln \left(\frac{P_{2}}{P_{0}}\right)=\beta_{0}+\beta_{1} \text { DISTANCE }+\beta_{2} \text { CLASSIFICATION }+\beta_{3} \text { GENDER }+\beta_{4} \mathrm{AGE}+\beta_{5} \text { EDUCATION } \\
& +\beta_{6} S T A T U S+\beta_{7} A V G_{-} W O R K+\beta_{8} W O R K_{-} C L A S S+\varepsilon_{9}
\end{aligned}
$$

$\begin{array}{ll}\text { Explanation: } & \\ \text { DISTANCE } & =\text { Distance to the respondent's workplace } \\ \text { CLASSIFICATION } & =\text { Town/ Cities Classification of Worker's residence } \\ \text { GENDER } & =\text { Worker's gender } \\ \text { AGE } & =\text { Worker's age } \\ \text { EDUCATION } & =\text { Year of schooling } \\ \text { STATUS } & =\text { Marriage status } \\ \text { AVG_WORK } & =\text { Average working hours per day } \\ \text { WORK_CLASS } & =\text { Worker's job classification } \\ \text { With Probability: } & \end{array}$


$\mathrm{P}_{0}=$ The probability of workers become stayers.

$\mathrm{P}_{1}=$ Probability of workers become commuter

$\mathrm{P}_{2}=$ The probability of workers become circular.

\section{Results}

\subsection{Patterns and Characteristics of the Metropolitan Area's Mobility in Indonesia}

The metropolitan area is a center for various economic activities. The complexity of the problem is united in this region. The metro area has a strategic nature, in addition to its role as a center for economic growth, a center for settlement, a center for socio-cultural activities, generally also as a center for government, and other important activities. What is examined from the metropolitan area is how the pattern of mobility is carried out by the workers in it. Labor mobility activities are categorized into three: Stayer, Commuter, and Circular. A stayer is a worker who has a place of work and a place to stay still in the same city area, then commuting is a workforce that resides differently from his workplace but commutes round-trip every day, and Circular workers are different workers between dwellings and where they work and commute round, weekly, monthly or more.

Based on the distribution of the number of stayers, commuters, and circulars there is no significant difference in each metropolitan area in Indonesia. The proportion of commuter workers starts from 20 - 40\%. Meanwhile, circular workers in each region are very small, only about $2 \%$ each. In terms of demographic distribution, the Metropolitan area outside of Java has similar demographic characteristics where the total number of workers in the region is in the range of 3,000 - 4,000 people with a stayer ratio of around $60-70 \%$. Also, there is no specific decision related to the determination of the ratio of stayers, movers, and circulars in regions in Indonesia because, for example, Jabodetabek with Kedungsepur. Kedungsepur has a higher Commuter rate $(41.69 \%)$ compared to Jabodetabek $(40.86 \%)$, even though the number of workers in Kedungsepur is only half that of Jabodetabek. The same thing also applies to areas with a small number of workers, regions that have a smaller population may not necessarily have a lowerr commuter ratio. What can be concluded is that the Metropolitan area on Java tends to have a higher commuter ratio.

\subsection{Worker Mobility Patterns by Distance to Workplace}

Based on its distribution in each Metropolitan area in Indonesia, the longer the distance to travel to the workplace, the higher the percentage of workers who become passengers. From the results of this distribution shows the results that the farther the distance, the higher the number of passengers, but if we count the change from Stayer to Commuter, the amount will decrease in each transportation category. Therefore, we can conclude that the longer the distance of travel, the less likely it is for workers to become circular.

\subsection{Worker Mobility Patterns According to Residence Classification}

According to the distribution of labor mobility patterns, the composition between Stayers, Commuters, and Circulars in the Metropolitan area in Indonesia is sufficient to maintain a similar disposition. Overall it appears that workers who live in the City have a higher Commuter ratio than in the Village. From the results of this distribution, we can say that the classification 
of residence has a positive influence on the pattern of non-permanent mobility, or the behavior of being a commuter will tend to occur more frequently in urban areas.

\subsection{Worker Mobility Patterns According to Gender Classification}

Based on distribution, it was found that man more dominate the Stayer ratio in the Metropolitan area in Indonesia. Overall, the workforce of women is more inclined to commute mobility. But if we look more closely, among the ratio of workers who do circular mobility, women have fewer rates than men. The gender variable has a negative influence on the tendency of workers to become commuters because statistically that the number of women who become commuters is higher than men. However, in the case of Circular, the opposite result occurs where the male sex will encourage the tendency of workers to become Circular.

\subsection{The Pattern of Labor Mobility According to the Age of the Workforce}

Based on the distribution, there is no clear pattern between the distribution of mobility patterns by age category. In the Jabodetabek and Bandung regions visible negative trends between age and Stayer ratio, but Sarbagita and Banjar Bakula, the opposite direcion is even niticeable. Besides that, the other area such as Palapa and Gerbangkertosusila, it shows an up and downtrend pattern. The indicates that the age of the workers will have a different effect on each Metropolitan area.

\subsection{Patterns of Labor Mobility According to Marital Status}

Based on the distribution pattern of labor mobility, the workers who have not or are not married tend to become a Commuter. In the distribution table, although it appears that each Metropolitan region has a similar ratio between the conditions of marriage and not married. However, it still seems that in each area, the rate of commuting is greater for workers who have registered marriage. Also applies to Circular workers, where the level of Circular workers is greater for married workers in each Metropolitan area.

\subsection{Pattern of Labor Mobility According to Education Level}

Overall, the workforce with tertiary education (Diploma, Bachelor, Master, or Doctoral) tends to have a higher Commuter ratio than other education categories. Even though in some Metropolitan areas show the opposite trend, but the trend where the higher the level of education, the higher the ratio of Commuting still dominates in most Metropolitan areas in Indonesia. This shows that there is a positive influence from the level of education on the pattern of non-permanent mobility in the metropolitan area in Indonesia.

\subsection{Regression Results in All Metropolitan Areas in Indonesia}

Table 2. Estimated Parameter of Non-Permanent Mobility Patterns of Workers in All Metropolitan Areas in Indonesia

\begin{tabular}{llllll}
\hline \multirow{2}{*}{ Variable } & \multicolumn{2}{c}{ Commuter } & \multicolumn{2}{c}{ Circular } \\
& & Coefficient & Std. Err. & Coefficient & Std. Err. \\
\hline \multirow{2}{*}{ DISTANCE } & $<10 \mathrm{Km}$ & $-0,779$ & $0,000 * * *$ & $-0,098$ & 0,000 \\
& $10-29 \mathrm{Km}$ & $-0,530$ & $0,000 * * *$ & $-0,098$ & 0,000 \\
\multirow{2}{*}{ CLASSIFICATION } & $-0,324$ & $0,000 * * *$ & $-0,098$ & 0,000 \\
\hline
\end{tabular}




\begin{tabular}{|c|c|c|c|c|c|}
\hline \multirow{2}{*}{ Variable } & & \multicolumn{2}{|c|}{ Commuter } & \multicolumn{2}{|c|}{ Circular } \\
\hline & & Coefficient & Std. Err. & Coefficient & Std. Err. \\
\hline GENDER & & $-0,042$ & $0,000 * * *$ & 0,034 & $0,000 * * *$ \\
\hline AGE & & $-0,0002$ & $0,000 * * *$ & $-0,0001$ & $0,000 * * *$ \\
\hline STATUS & & $-0,007$ & $0,000 * * *$ & 0,012 & $0,000 * * *$ \\
\hline EDUCATION & & 0,008 & $0,000 * * *$ & 0,0004 & $0,000 * * *$ \\
\hline AVG_WORK & & $-0,001$ & $0,000 * * *$ & 0,001 & $0,000 * * *$ \\
\hline \multirow{2}{*}{ WORK_CLASS } & Industry & 0,079 & $0,000 * * *$ & $-0,001$ & $0,000 * * *$ \\
\hline & Service & 0,077 & $0,000 * * *$ & 0,004 & $0,000 * * *$ \\
\hline
\end{tabular}

Significant at level: $* * *=1 \% ; * *=5 \% ; * 10 \%$

Source: SAKERNAS 2018,processed

Based on the estimation results, the variable distance to the workplace (distance) results in a negative coefficient by the initial hypothesis that travel distance has a negative impact on the probability of the workforce choosing to be a Commuter or Circular compared to being a Stayers. Then for each distance interval category, the difference in the coefficient values obtained illustrates that the longer the distance traveled, the smaller the influence of distance traveled in reducing the probability of labor to become a Commuter. In the village/city classification variable, a positive coefficient means that if the workforce lives in a place that is classified as an urban area, then the possibility of the workforce becoming Commuter or Circular will increase. These results are consistent with the initial hypothesis of the study that if workers live in urban areas, it will increase the likelihood of workers choosing to become a Commuter or Circular. Based on the assumption that between the central city of the metropolitan area and the city around it has a better level of accessibility compared to rural areas that are still in the same metro area so that mobility will be easier to do between the central cities than the central villages.

In the gender variable different results are obtained between the results for commuter and circular. In the results of commuting, if the workforce is male, then the possibility of becoming a commuter will be reduced. Meanwhile, in a circular result, if the workforce is male then the chances of becoming circular will increase. The effects on commuting are not by the initial hypothesis that male sex should have a higher probability of becoming a commuter than women.

Then the age variable of the respondents obtained significant results on both the results of the study and the results of the commuter or circular results got contrary, which indicates that the older the workforce, the less likely it is to become a commuter. It consistent with the initial hypothesis that young workers tend to become commuter or circular workers compared to middle-aged workers.

Then the estimation results of marital status variables in all metropolitan areas in Indonesia obtained results where if the workforce is married or married, the probability of the labor to become a commuter and circular will increase. The effects of this estimation contrast with the initial hypothesis, which states that marital status will negatively influence the choice to become a Commuter or Circular.

For education variables, positive coefficient values are obtained for both outcomes (commuting and circular), which means that the higher the level of education completed by workers, the higher their probability of becoming a commuter or circular. These results are consistent with the initial hypothesis that education has a positive effect on mobility choices because it is assumed that people with higher education have awareness of higher spending. Thus, in the long run, people with higher education level will tend to choose to become commuters with lower costs. 


\section{Conclusion}

This study found that demographic character and location of residence influence on patterns of labor mobility in Metropolitan areas in Indonesia. Positive or negative interaction coefficients in this study indicate that demographic characteristics and workforce location have a significant influence on the pattern of labor mobility in fourteen Metropolitan areas in Indonesia. Even so, the distance variable has not been able to explain the effect of location of residence well because the results are not significant on the circular pattern in each Metropolitan area

Each Metropolitan region has the same mobility pattern, with the influence of the variables studied have a similar relationship. However, in the sub-variable level, there are several cases wherein a specific region, the results of the estimation of a variable have a different effect than the majority results. Although several factors have different effects on certain Metropolitan regions, in general, the majority of Metropolitan areas in Indonesia have similar mobility characteristics.

\section{Suggestion}

Linking the migration transition theory with the development of urban infrastructure, in this research, the author tries to provide advice for the government to improve and equitable public facilities such as toll roads, inter-city roads, and public transportation to make efficient the mobility of labor. As explained in literature review, in the Skeldon migration stage, where movement, which was initially dominated by urbanization, is increasingly changing, the stage will change to inter-city migration until eventually technological sophistication will facilitate activities and reduce population mobility. Therefore, to be able to push population mobility to a higher stage, the role of the government in improving the media of labor mobility is needed.

\section{Reference}

[1] Axisa, J. J., Newbold, K. B., \& Scott, D. M. (2012). Migration, urban growth, and commuting distance in Toronto's commuter shed. Area, 344-355.

[2] Badan Pusat Statistik. (2014). Statistik Komuter Jabodetabek. Jakarta: Badan Pusat Statistik.

[3] Badan Pusat Statistik. (2018). Survei Angkatan Kerja Nasional 2018. Badan Pusat Statisitik.

[4] Bappenas. (2014, Oktober 07). Kebijakan Pembangunan Perkotaan dan Pedesaan Pengembangan Ekonomi Lokal Melalui Kerjasama Antardaerah. Solo, Jawa Tengah, Indonesia.

[5] Bruin, J. (2006). MULTINOMIAL LOGISTIC REGRESSION | STATA DATA ANALYSIS EXAMPLES. Retrieved from UCLA: https://stats.idre.ucla.edu/stata/dae/multinomiallogisticregression/

[6] Cameron, G., \& Muellbauer, J. (1998). The Housing Market and Regional Commuting and Migration Choices. Scottish Journal of Political Economy.

[7] Ciptakarya. (2018, Oktober 24). Penyusunan Masterplan Metropolitan Mataram Raya Pasca Bencana Gempa di NTB. Retrieved from Kementerian Pekerjaan Umum dan Perumahan Rakyat: http://ciptakarya.pu.go.id/v5/berita/detail/Ciptakarya/8955/Penyusunan-Masterplan-MetropolitanMataram-Raya-Pasca-Bencana-Gempa-di-NTB

[8] Kawase, M. (2004). Changing gender differences in commuting in the Tokyo metropolitan suburbs. GeoJournal, 247-253.

[9] Lee, B. S., \& McDonald, J. F. (2002). Determinants of Commuting Time and Distance for Seoul Residents: The Impact of Family Status on the Commuting of Women. Urban Studies, 1283-1302.

[10] Lee, E. S. (1966). A Theory of Migration. Demography, 47-57. 
[11] Mantra, I. B. (1981). Population Movement in Wet Rice Communities: A Case Study of Two Dukuh in Yogyakarta Special Region. Yogyakarta: Gadjah Mada University Press.

[12] Mark, M., Katz, B., Rahman, S., \& Warren, D. (2008). MetroPolicy: Shaping A New Federal Partnership for a Metropolitan Nation. 4-103.

[13] O'Sullivan, A. (2012). Urban Economics. New York: McGraw-Hill/Irwin.

[14] Pariaman Today. (2014). Kota Metropolitan PALAPA? Antara Ide dan Kenyataan. Retrieved from Pariaman Today: http://www.pariamantoday.com/2014/07/kota-metropolitan-palapa-antara-idedan.html?m=1

[15] Percaya, A. S. (2018). Gender, Employment, and Commuting: Assesing Spatial Entrapment of Women in Indonesia.

[16] Preston, V., McLafferty, S., \& Hamilton, E. (1993). THE IMPACT OF FAMILY STATUS ON BLACK, WHITE, AND HISPANIC WOMEN'S COMMUTING. Urban Geography, 228-250.

[17] Punpuing, S. (1992). Correlates of Commuting Patterns: A Case-study of Bangkok, Thailand. Urban Studies, 527-546.

[18] Schwanen, T., \& Dijst, M. (2001). Travel-time ratios for visits to the workplace: the relationship. Transportation Research Part A, 573-592.

[19] Skeldon, R. (1990). Population Mobility in Developing Countries. Belhaven Press.

[20] Solobaru. (2016, Maret 01). Jadi Metropolitan, Solo Baru Butuh Perhatian Pemerintah. Retrieved from Solo Baru: http://solobaru.com/jadi-metropolitan-solo-baru-butuh-perhatianpemerintah

[21] Squires, G. E. (n.d.). Urban Sprawl: Causes, Consequences, \& Policy Responses. The Urban Institute Press, 2002.

[22] Susiyanto, G. A. (2018). Mobilitas Non Permanen Tenaga Kerja DI SEPULUH KAWASAN METROPOLITAN INDONESIA.

[23] Thompson, J. H. (1956). Commuting Patterns of Manufacturing Employees. ILR Review, 70-80.

[24] Trendle, B., \& Siu, J. (2005). Commuting Patterns of Sunshine Coast Residents and the Impact of Education.

[25] Utama, F. R. (2016, November 02). Rencana Pengembangan Dua Kawasan Metropolitan Baru Mulai. Retrieved from Okefinance: https://economy.okezone.com/read/2016/11/02/470/1531198/rencana-pengembangan-dua-kawasanmetropolitan-baru-mulai-disusun

[26] Utama, F. R. (2016, November 02). Rencana Pengembangan Dua Kawasan Metropolitan Baru Mulai Disusun. Retrieved from OKEfinance: https://economy.okezone.com/read/2016/11/02/470/1531198/rencana-pengembangan-dua-kawasanmetropolitan-baru-mulai-disusun

[27] White, M. J. (1986). Sex Differences in Urban Commuting Patterns. The American Economic Review, 368-372.

[28] Yudhistira, M. H., Indriyani, W., Pratama, A. P., Sofiyandi, Y., \& Kurniawan, Y. R. (2017). Transportation network and changes in urban structure: Evidence from the. Research In Transportation Economics.

[29] Yudis. (2016, November 03). Pemerintah Kembangkan Kota-Kota Metropolitan Baru Yang Ramah Investasi. Retrieved from HousingEstate: http://housingestate.id/read/2016/11/03/pemerintahkembangkan-kota-kota-metropolitan-baru-yang-ramah-investasi/

[30] Zelinsky, W. (1971). The Hypothesis of the Mobility Transition. Geographical Review, Vol 61, 219-249. 